\title{
Memes and Entomology: A didactic sequence through Ecuadorian students'
}

\section{perspective}

\author{
Memes y Entomología: Una secuencia didáctica a través de la perspectiva de estudiantes \\ ecuatorianos
}

Memes e Entomologia: Uma sequência didática através da perspectiva dos estudantes equatorianos

\begin{abstract}
This study aims at presenting memes as a teaching technique and the students' perspectives on the use of memes in education. Two groups of 35 and 31 students, ranged from 18 to 33 years old, enrolled in the entomology classes in a public university in Ecuador, participated in this project. The didactic sequence was put into practice from November 2020 to March 2021, and it was based on Marcuschi (2008). Students were asked to create a meme related to each unit of the course. To collect the data, one online questionnaire was used to get to know the participants' perspectives at the end of the semester. The results showed that the participants saw the use of memes as an untraditional type of class with positive outcomes. Also, they saw memes as a fun tool for educational purposes. So, we consider memes an essential and powerful tool for education because they permit interactivity among students, raise curiosity, foster motivation, nurture critical thinking, and help students remember the previously learned content. Considering the positive outcome of this research, we believe this study is addressed for professors of higher education in the area of Entomology who seek new methodologies to be used in class.
\end{abstract}

Keywords: Memes; Entomology, Teaching; Tertiary context; Ecuador.

\section{Resumen}

Este estudio tiene como objetivo presentar los memes como técnica de enseñanza y las perspectivas de los estudiantes sobre el uso de los memes en la educación. En este proyecto participaron dos grupos de 35 y 31 estudiantes, con edades comprendidas entre los 18 y los 33 años, matriculados en la unidad de aprendizaje de Entomología de una universidad pública de Ecuador. La secuencia didáctica se puso en práctica desde noviembre de 2020 hasta marzo de 2021, y se basó en la propuesta de Marcuschi (2008). Se pidió a los estudiantes que crearan un meme relacionado con cada unidad del curso. Para recopilar los datos, se utilizó un cuestionario en línea para conocer las perspectivas de los participantes al final del semestre. Los resultados mostraron que los participantes identificaron el uso de memes como un tipo de clase no tradicional con resultados positivos; además, de considerarlos como una herramienta divertida con fines educativos. Por lo tanto, y de acuerdo a los resultados obtenidos, consideramos que los memes son una herramienta esencial y poderosa para la educación universitaria porque permiten la interactividad entre los estudiantes, despiertan la curiosidad, fomentan la motivación, nutren el pensamiento crítico y ayudan a los estudiantes a recordar el contenido aprendido previamente. Considerando el resultado positivo de esta investigación, consideramos que este estudio está dirigido a profesores de educación superior en el área de Entomología que buscan nuevas metodologías para ser utilizadas en clase.

Palabras clave: Memes; Entomología; Enseñanza; Educación superior; Ecuador.

\section{Resumo}

Este estudo tem como objetivo apresentar os memes como técnica de ensino e as perspectivas dos alunos sobre o uso dos memes na educação. Participaram deste projeto dois grupos de 35 e 31 alunos, com idades entre 18 e 33 anos, matriculados nas aulas de entomologia de uma universidade pública do Equador. A sequência didática foi colocada em prática de novembro de 2020 a março de 2021, e foi baseada em Marcuschi (2008). Os alunos foram convidados a criar um meme relacionado a cada unidade do curso. Para a coleta de dados, foi utilizado um questionário online para conhecer as perspectivas dos participantes ao final do semestre. Os resultados mostraram que os participantes viram o uso de memes como um tipo de aula não tradicional com resultados positivos. Além disso, eles viam os memes como 
uma ferramenta divertida para fins educacionais. Portanto, consideramos os memes uma ferramenta essencial e poderosa para a educação porque eles permitem a interatividade entre os alunos, aumentam a curiosidade, estimulam a motivação, fomentam o pensamento crítico e ajudam os alunos a lembrar o conteúdo aprendido anteriormente. Considerando o resultado positivo desta pesquisa, acreditamos que este estudo esteja dirigido a docentes do ensino superior da área de Entomologia que buscam novas metodologias para serem utilizadas em sala de aula.

Palavras-chave: Memes; Entomologia; Ensino; Ensino superior; Equador.

\section{Introduction}

One of the main challenges of contemporary education, at any level, is to promote practices that allow students active participation in activities of the digital culture (Souza, 2019). Technology has become a crucial tool to be used in class when accompanied by goals and purposes. Its use has demonstrated advantages for the teachers who lead with the 21-century student and other generations. Some examples are the increase in motivation and participation.

Through the use of technology, it is possible to privilege other spaces besides the class. Consequently, teachers can bring different cultures and work with different subjects simultaneously, resulting in an interdisciplinary way that can involve different languages, spaces, and times (Almeida, 2020). The meme is an influential 21-century genre that helps teachers work with this interdisciplinary idea. A meme is a picture or a text, usually shared on social media, that aims to make people laugh or foster critical thoughts.

Teachers, who opted to break the traditional teaching method and decided to teach using a contextualized approach, recently started to incorporate this genre in class since it makes part of the students' daily lives (Purnama, 2017; Santos et al., 2020; Silva et al., 2019; Wells, 2018). This tool allows the educator to apply the active methodology in class. Students are the center of the learning and the knowledge seekers, while the teacher is just the facilitator, the guide. So, getting to the knowledge demand more and more autonomy from the student (Pereira \& Santana, 2018); therefore, they are entirely involved in the class. Despite all these positive effects on students, many studies use memes in a secondary context in different subjects, and few focused on the tertiary context. Ecuador, where this didactic sequence was developed, lacks studies using this multimodal genre, especially in the agronomy course.

For this reason, researches on new pedagogies to be used in the tertiary Ecuadorian environment is still necessary to be developed and shared. Thus, this study aims to present a didactic sequence using memes in a university context and the students' perspectives on using this genre for educational purposes.

\section{Methodology}

\subsection{The didactic sequence}

Based on Marcuschi (2008), this didactic sequence was done throughout the entomology classes from November 2020 to March 2021. It was divided into three different steps. In the first phase, the professor worked with the genre meme in class. It was presented its characteristics, goal, purpose. During this step, some memes were shown in order to make students acquainted with entomological memes. Students were invited to bring their personal experiences to the class. Some said they liked to use memes in social media; some said they did know when the term meme was invented. This phase was critical because the knowledge was built together with the student's background.

In the second phase, students were invited to create their memes; this part had a significant duration. At the end of each topic, one meme was created. Their memes needed to portray one idea referring to the topic previously studied. After that, the memes were shown in class to make students discuss their final results and assess their classmates, aiming for improvements for the following memes. This stage was rich because some discussions were generated, some vital points of view were offered, and, in the meantime, students were discussing the entomology topics. 
Finally, the last phase was done at the end of the semester. One online questionnaire was applied to get to know students' opinions about the meme activity. The questionnaire was divided into two parts. The first one included questions to get the students' profile, and in the second part, the questions were focused on the meme activity.

Graphic 1 describes the didactic sequence based on Marcuschi's model (2008), which points to: (I): the presentation of the situation/the initial production; (II): the modules (meme creation); and (III) the final production.

Graphic 1. Didactic sequence steps based on Marcuschi (2008).

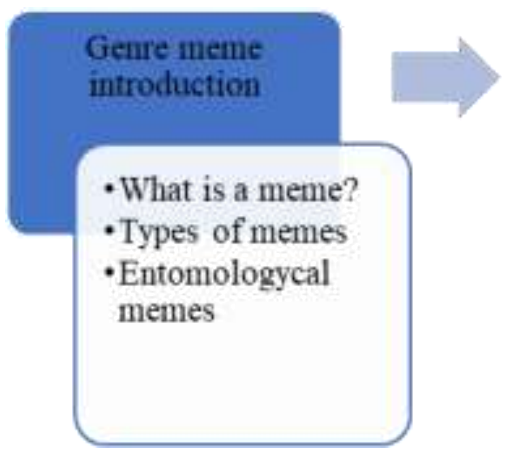

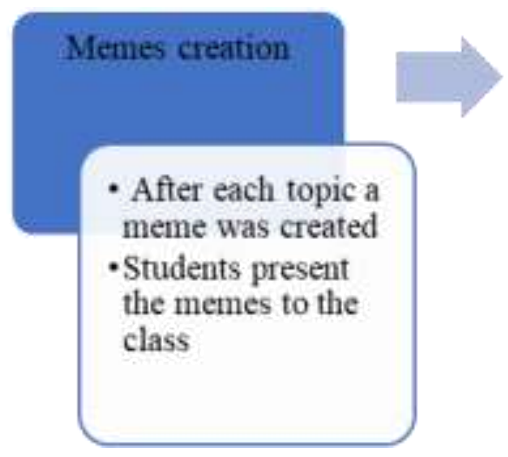

Source: Authors.

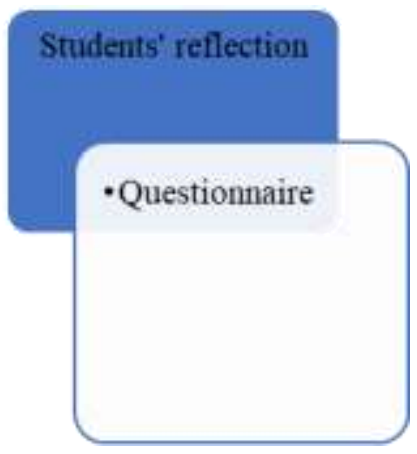

\subsection{Setting and participants}

This study was undertaken in a public university in the Los Rios Province, Ecuador. The participants were two groups of second-year students of the Faculty of Agronomy enrolled in Entomology subject. In group A there were 35 students, and in group B, there were 31. Their ages ranged from 18 to 33. Because of the covid-19 pandemic, the classes were done online through Google Meets. Students had three synchronous class hours every week and four hours of asynchronous classes in the university learning platform.

\subsection{Memes}

The term meme was first coined by the biologist Richard Dawkins (1976) in his studies called "The Selfish gene." It was used "to describe gene-like infectious units of culture that spread from person to person" (Shifman, 2013, p.362). Its definition and uses have changed until getting to the internet meme known nowadays (Souza, 2014). Currently, a meme has a different definition than it used to have. Now it is defined as "a piece of culture, typically a joke, which gains influence through online transmission" (Davison 2012, p. 122).

The influence of the internet and social networks made this new 21-century genre be spread and used worldwide. However, understanding the meaning of a meme is necessary to know the context and time it was created (Chagas, 2016). The background is so essential that Jones and Schieffelin (2009) and Burgess (2008) were able to use memes to understand some aspects of current culture since they portray the behavior, beliefs, thought, and actions of a community (Knobel \& Lankshear, 2007).

Memes on the internet can be encountered in two different versions: video or images (Borzsei 2013). These ways of been presented helped the memes quickly sharing on the web, making them an essential instrument for everyone. Memes have an extensive taxonomy. There are daily life situations until serious issues as politician criticism. They can express everything; "feelings, political stance, indignations, wishes, ironies, and complaints (Santos and Souza, 2019, p.80). There are endless possibilities for its use. 


\subsection{Memes in education}

Memes have been used in the education context for different purposes. Santos et al. (2020) made a state of art study about memes' uses in the educational field. They found out that $67 \%$ of the teachers' have already used memes as a pedagogical resource and the large majority are from the secondary context. The reason is that they make learning meaningful to students.

Silva et al. (2019) used memes during the Portuguese class in a didactic sequence. Students created political memes and reflected on the situation in Brazil. Wells (2018) also worked with memes and politicians in the American context, but her main goal was to foster student's critical thinking. In the end, students were required to write an essay about the topic. She realized that doing memes before helped students develop the theme better.

Purnama (2017), on the other hand, used memes to enhance students' participation and engagement in class. She worked with $23 \mathrm{EFL}$ students of Health College students. At the end of her study, she concluded that students felt relaxed during the classes because of memes; consequently, they were engaged to participate since they did not see learning English as an obligation. Many studies used memes as a pedagogical tool; each one of them focused on a different educational purpose. In general, they wanted to increase motivation and foster critical thinking, but they all have positive results for the students.

\section{Results and Discussion}

In this section, some memes that the students created are presented in order to see how they combined the learning topic with this genre. After, the participants' perspectives on the activity are portrayed according to their answers in the questionnaire.

\subsection{Memes}

We now present three memes made by the students. The first one is necessary to know the pop culture to understand the humor generated. The second focuses on local culture so that Ecuadorian people might have no difficulties understanding. Finally, the last meme uses specific knowledge of the entomology field. 


\section{Figure $1^{1}$}

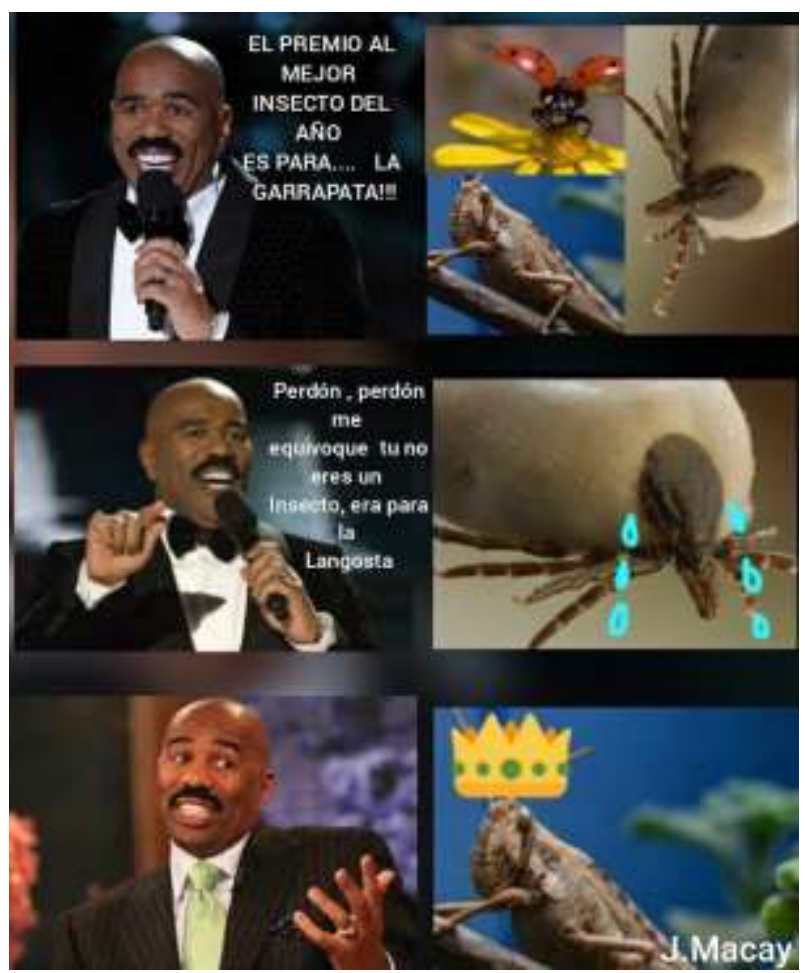

Source: Authors.

Broderick Stephen "Steve" Harvey is a world-famous American actor, comedian, television host, radio host, and author. In 2015, Harvey was chosen to be the presenter of the Miss Universe beauty pageant held in Las Vegas, United States. The actor mistakenly announced the beauty pageant winner, the participant from Colombia, Ariadna Gutiérrez. Her compatriot Paulina Vega, Miss Universe 2014, placed the crown on her. However, a few minutes later, Harvey had to clarify the error and announced Miss Philippines Pia Alonzo Wurtzbach as the winner. In the meme, a situation similar to the one that occurred in Miss Universe was described. The actor announces the tick as the best insect of the year, but ticks do not belong to the Insecta class but the Arachnid class. So, the presenter retracts and announces the locust as the best insect of the year. According to the situation, the tick of the meme took the place of Ariadna Gutiérrez while that of the locust was Pia Alonzo Wurtzbach; an interesting way to show that ticks are not insects.

\footnotetext{
${ }^{1}$ Translation: The prize for best insect goes to the tick. - Sorry, sorry, I made a mistake. You are not an insect, so it goes to the locust.
} 


\section{Figure $2^{2}$}

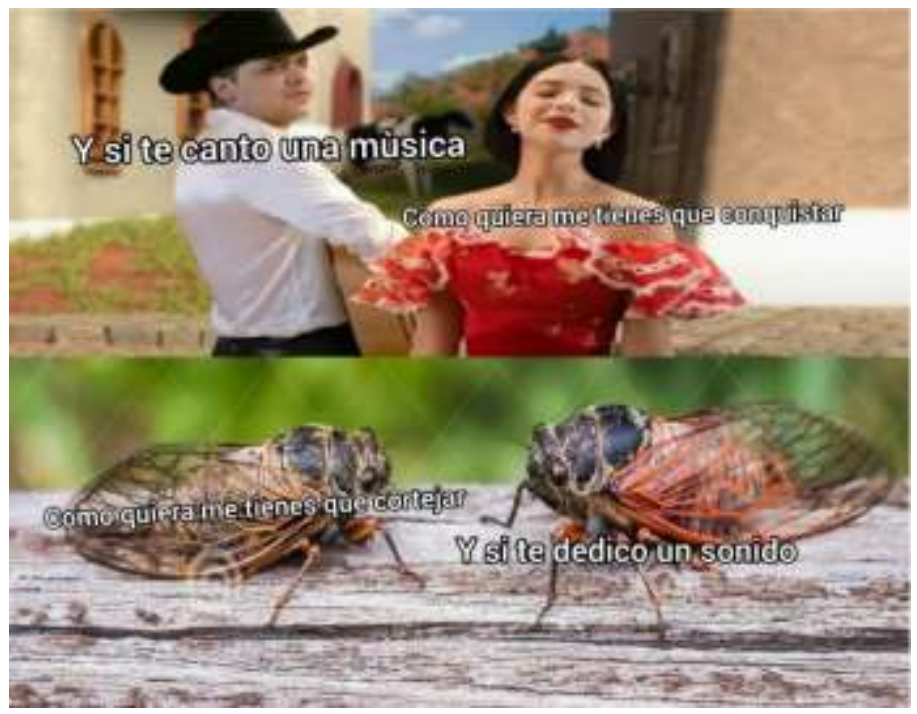

Source: Authors.

Generally, to win the affection or attention of a woman, men look for methods to get closer to them; For example, some methods used may be offering gifts, being thoughtful, romantic, asking her out to a restaurant, or even dedicating a song to her. Among insects, various male species' behavior is not far from what occurs in humans. For example, acoustic comportment plays an essential role in cicada biology, such as reproduction and intrasexual competition (Luo \& Wei, 2015). In cicadas, the sound is emitted by the tymbal organ, which is essentially composed of a ribbed membrane at the abdomen's base and an attached muscle. Sounds are produced when the tymbal muscle activity distorts the stiff membrane (Luo \& Wei, 2015). In the meme, the student compares how a man can conquer a woman through songs, while male cicadas can do it through sounds. The student reviewed the content in order to generate her entomological meme.

\section{Figure $3^{3}$}

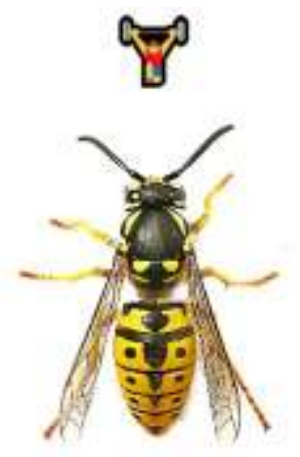

Cuándo querias terminar el año con abdomen de avispa (pedunculado)

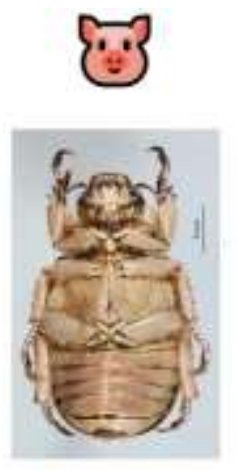

Pero lo terminas con el abdomen de escarabajo (sesil)

Source: Authors.

\footnotetext{
${ }^{2}$ Translation: If I sing you a song. As you wish, you have to try to win my heart. / If I dedicate to you a sound. As you wish, you have to try to win my heart.

${ }^{3}$ Translation: When you want to finish the year with a wasp's abdomen. But you ended up finishing with a beetle's abdomen.
} 
Insects have different abdomen types, depending on the chest's connection: sessile, free and pedunculated abdomen. In the sessile abdomen, the adherent connects to the chest in its entire width. Ex.: cockroaches, grasshoppers, beetles. The open abdomen has a slight constriction at the junction of the abdomen and chest. E.g., flies, bees, butterflies. The pedunculated abdomen presents marked constriction in the second or second and third abdominal segments, the first abdominal segment that fuses with the metathorax. Ex: ants and wasps. The meme compared the types of abdomen and insects with what could happen to the man's abdomen at the end of the year. Instead of having a perfect body with a defined abdomen, the meme indicated that a secular abdomen was obtained. Alluding to how much weight and strength it has.

\subsection{Students' feedback on the didactic sequence}

During the questionnaire, many opinions came out about the didactic sequence. They all were positive, and students mentioned interesting ideas on using memes in the class. The following shows these points of view on the use of memes in Entomology class. Later we show the meme creation process made by the students and consequences on learning.

\subsubsection{Opinions on the use of memes in Entomology class}

The participants pointed out many constructive perspectives on using memes during the class. Almost $80 \%$ said that the class became funnier and relaxing when they had to work with memes. One student said, "It is a fun way to learn and understand (Questionnaire)." Another student complemented this idea saying that "the use of memes in the subject is fascinating and fun. It has allowed us to understand the subject more creatively and expand our analysis and interpretation area (Questionnaire)." Baysac and Emmanuel (2017) found out the same opinion with their students. Their participants said that the class became funnier and more relaxing through the use of memes. Bringing humor to the educational context is essential because it fosters learning and produces a more positive classroom atmosphere (Garner, 2005). According to Stebbings (1980), any type of humor can deliver social comic relief. Consequently, it can decrease anxiety and keep people thinking (Torok et al., 2010). The two quotes showed the power of this tool to the learning context. This new methodology works with the wellbeing of the students and helps them improve their cognitive area.

Students were able to realize that the use of memes in education is not the archetypal standard classes. One participant said, "Memes break the schemes of typical standard classes." (Questionnaire). This active methodology places students in the center of the learning. They change their passive agent condition in the learning process to an active learning condition; in other words, they act effectively in constructing knowledge itself (Campagnolo et al., 2014).

\subsubsection{Meme creation and consequences on learning}

Creating a meme involves many different processes; it will depend on the type of message you want to transmit. Sometimes you can criticize something or make people laugh. Students were asked what they took into account in their meme creation process. Many different opinions appeared, but they all shared one similarity: they searched for more information about the topic learned to create the meme.

One participant said, "I investigated what the teacher was teaching. Then I looked for information on a specific insect to make my entomological meme. Finally, I summarized everything learned in an image in a fun way (Questionnaire)." Another participant shared the same idea "I reviewed the classes, the topics that I have already seen and then I found a way to make a meme with an insect that I like (Questionnaire)." Both opinions demonstrated that students needed to revise the class content in order to make their memes. The first student searched on the internet for more information, and the second student reviewed the class recorded.

Searching for more information on the content helped students with the learning. They started to become more 
autonomous in learning. When the information they had was not sufficient, they looked for more. According to Berbel (2011), active methodologies can stimulate autonomous motivation in the student since they bring to the classes elements before not considered for them.

Furthermore, students were able to remember the knowledge easily because this process took time. Two participants declared, "The memes helped me remember the information (Questionnaire) and "A meme influences a lot since sometimes we forget things, and when we see the information portrayed in a meme, we remember it and even in a funny way." In an age in which students are constantly in touch with many types of information, remembering something may be difficult. When the learner saw the meme, they remembered the creation process and, consequently, recalled the content.

Another positive consequence of learning was fostering creativity in students. This multimodal genre permits the creator to make inferences on different cultural aspects, allowing students to play around. One participant confirmed this idea; she said, "memes helped me by improving my creativity in the subject because it is a new and creative format that makes us focus on the entomology content " (Questionnaire). According to Felinto and Santaella (2012, p. 22), "creativity means the production of new and differentiation." So, each meme is different for those who created and for those who analyze them.

\section{Final Considerations}

This research aimed to present an entomological didactic sequence to be used with tertiary students using memes and these participants' perspectives on this activity. The results showed that memes are an essential tool for education because they permit interactivity during the online class, raise curiosity, and foster motivation in students. Also, through the meme creation process, students need to revise the content to get what they expect. So, later on, when learners see their memes, they can remember the content.

The fact that memes are a multimodal genre allowed multiple interpretations and discussions during the class. Consequently, this made learners nurture their critical thinking and, at the same time, making them have fun. Through their answers during the interview, it was possible to see their excitement in using this genre. The teacher's role is to break the learning barriers and create a safe and comfortable learning environment. So, bringing to class the language used and the experiences lived outside the university walls gives a purpose and a meaning to students learning. It is up to the teacher to invest in active methodologies to break the traditional way of teaching. Considering the positive outcome of this research, we believe this study is addressed for tertiary professors who seek new methodologies to be used in class. Also, we recommend new studies on memes in a tertiary context. We suggest studies on the use of memes to enhance student's critical thinking, foster students` motivation, and increase classroom participation during the online learning context.

\section{References}

Almeida, S. (2020). Memes como estratégias pedagógicas na EaD para professores. Revista Interdisciplinar Parcerias Digitais, 1(2), 1-10. https://cp2.g12.br/ojs/index.php/parceriasdigitais/article/view/2319

Baysac, B., \& Emmanuel, P. (2017). Laughter in class: Humorous memes in 21 st century learning. Journal of Social Sciences (COES\&RJ-JSS), 6(2), 267-281. https://doi.org/10.25255/jss.2017.6.2.267.281

Berbel, N. (2011). As metodologias ativas e a promoção da autonomia de estudantes. Semina: Ciências Sociais e Humanas, 32(1), 25-40. http://dx.doi.org/10.5433/1679-0383.2011v32n1p25

Borzsei, L. (2013). Makes a Meme Instead: A Concise History of Internet Memes. New Media Studies Magazine 7.

Burgess, J. (2008). All your chocolate rain are belong to us? Viral video, YouTube and the dynamics of participatory culture. In: Lovink G and Niederer S (eds) Video Vortex Reader: Responses to YouTube. Amsterdam: Institute of Network Cultures, pp. 101-109.

Campagnolo, R., Dambros, A., Rauber, J., \& Tratch, R. (2014). Uso da abordagem peer instruction como metodologia ativa de aprendizagem: um relato de experiência. Revista Signos, 35(2), 79-87. http://www.univates.br/revistas/index.php/signos/article/view/775 
Chagas, V. (2016). Memes, engajamento político e ação coletiva, ou Por que o 'vomitaço' importa? \#MuseudeMemes. https://www.museudememes.com.br/memes-engajamento-politico-e-acao-coletiva-vomitaco-1/

Davison, P. (2012). The Language of Internet Memes. In The Social Media Reader, ed. Michael Maniberg. New York University Press, pp. $120-134$.

Dawkins, R. (1976). The Selfish Gene. Oxford, UK: Oxford University Press.

Felinto, E., \& Santaella, L. (2021). O explorador de abismos: Vilém Flusser e o pós-humanismo. Paulus

Garner, R. (2005). Humor, analogy, and metaphor: HAM it up in teaching. Radical Pedagogy, 6(2), 1. https://radicalpedagogy.icaap.org/content/issue6_2/garner.html

Jones, G. \& Schieffelin, B. (2009). Talking text and talking back: "My BFF Jill" from boob tube to YouTube. Journal of Computer-Mediated Communication, 14(4), 1050-1079. https://doi.org/10.1111/j.1083-6101.2009.01481.x

Knobel, M., \& Lankshear, C. (2007) A New Literacies Sampler. Peter Lang.

Luo, C., \& Wei, C. (2015). Stridulatory sound-production and its function in females of the cicada subpsaltria yangi. PLoS ONE 10(2), 1-13. https://doi.org/10.1371/journal.pone.0118667

Marcuschi, L. (2008). Produção textual, análise de gêneros e compreensão. Parábola Editorial

Pereira, P., \& Santana, A. (2018). Metodologias ativas: um estudo quantitativo-descritivo com estudantes de Pedagogia de um Centro Universitário em Jaboatão dos Guararapes-PE. Revista Olhar Científico. 4(1), 693-728.

Purnama, A. (2017). Incorporating Memes and Instagram to Enhance Student's Participation. LLT Journal: A Journal on Language and Language Teaching, 20(1), 1-14. https://doi.org/10.24071/1lt.v20i1.404

Santos, A., Dantas, L. F. S., Alves, T. R. S., \& Braga, E. S. O. (2020). The use of memes as a pedagogical resource in the chemistry teaching: a view of the teachers of the discipline. Research, Society and Development, 9(7): 1-23. https://doi.org/10.33448/rsd-v9i7.4020

Santos, M., \& Souza, N. (2019). O uso dos memes como instrumento de ensino para alunos do ensino fundamental. Porto Das Letras, 5(2), 78-89. https://sistemas.uft.edu.br/periodicos/index.php/portodasletras/article/view/7593

Shifman, L. (2013). Memes in a digital world: reconciling with a conceptual troublemaker. Journal of Computer-Mediated Communication 18(3), 362-377. https://doi.org/10.1111/jcc4.12013

Silva, L., Pezarino, M., \& Caetano, J. (2019). Criação de Memes: Uma proposta de Sequência Didática. Anais do Encontro Virtual de Documentação em Software Livre $\quad$ Congresso Internacional de $\quad$ Linguagem $\quad$ Online, http://www.periodicos.letras.ufmg.br/index.php/anais_linguagem_tecnologia/article/view/16225

Souza, J. (2014). Memes pluralistas - práticas linguístico-midiáticas em fenômenos bilíngues: um estudo sistêmico-funcional e multimodal sobre propagação via corpora digitais. (Master's Thesis). http://www.bdtd.uerj.br/tde_busca/arquivo.php?codArquivo=8781

Souza, M. (2019). Memes de internet e educação: uma sequência didática para as aulas de História e Língua Portuguesa. Periferia, 11(1), 193-213. https://doi.org/10.12957/periferia.2019.37016

Stebbins, R. (1980). The Role of Humour in Teaching: Strategy and Self-Expression. In Teacher Strategies. Explorations in the Sociology of the School, edited by P. Woods, 84-97. Croom Helm

Torok, S., McMorris, R., \& Lin, W. (2010) Is humor an appreciated teaching tool? Perceptions of professors' teaching styles and use of humor. College Teaching, 52(1), 14-20. https://doi.org/10.3200/CTCH.52.1.14-20

Wells, D. (2018): You All Made Dank Memes: Using Internet Memes to Promote Critical Thinking, Journal of Political Science Education, 14(2), 240-248. https://doi.org/10.1080/15512169.2017.1406363 